Slavic and East European Subsection

Wednesday, January 29, 2:00-4:30

p.m.

Executive Committee

Wednesday, January $29, \quad 8: 00$ 10:30 p.m.

University Libraries Section

Academic Status Committee ( $a d$ hoc)

Monday, January 27, 2:00-4:00 p.m.

Extension Library Service Committee
Tuesday, January 28, 10:00-12:00 noon

Wednesday, January 29, 2:00-4:00 p.m.

Urban Universities Library Committee

Thursday, January 30, 8:00-9:30 a.m.

Emerson Jacob Richard A. Davis

\title{
Nominations Sought for Freedley Award
}

The "George Freedley Memorial Award" has been established by the Theatre Library Association to honor the late founder of the Association, theatre historian, critic, author, and first curator of the Theatre Collection of the New York Public library. To be given annually, the award has as its purpose to recognize a published work in the field of the legitimate theatre published in the United States. A citation will be made to the author "on the basis of scholarship, readability, value in the work of theatre librarians, and general contribution to the broadening of knowledge." The selection of the recipient will be determined by a fivemember jury appointed by the President of the
Theatre Library Association.

Authors, publishers, and members of the Association are invited to submit nominations in writing for the 1968 Freedley Award to Chairman of the Jury, Professor Robert H. Ball, 11 North Washington Street, Port Washington, New York 11050. The Nominee's name must be accompanied by the title and publisher of his book and must indicate the value, scope and unique features of the book so nominated. Authors and publishers must submit published copies for consideration. No galley-sheets or proofs will be accepted. All nominations must be in the hands of the jury by January 15 , 1969.

\section{LATEST CATALOG LISTING.
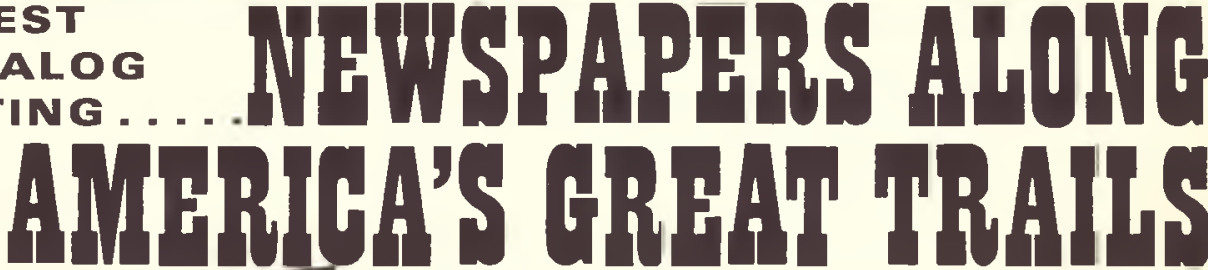

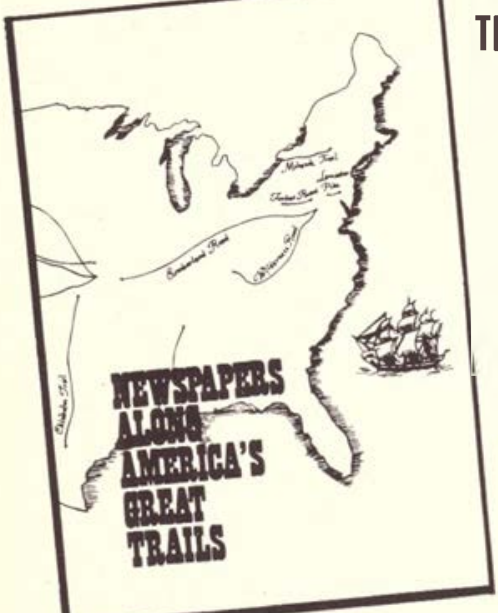

\section{These Newspapers May Be Purchased on 35mm Microfilm}

Bell \& Howell compiled this new catalog of Newspapers Along America's Great Trails to help researchers and historians recapture the real vitality that was America coming to life along her growing frontiers.

All newspapers listed in the catalog are part of the archival collection in Bell \& Howell's Micro Photo Division vaults. They have been selected for this catalog because of their special interest to students of America's frontiers.

Please write for your free copy from:

\section{MICRO PHOTO DIVISION}

1700 SHAW AVE. CLEVELAND, OHIO 44112

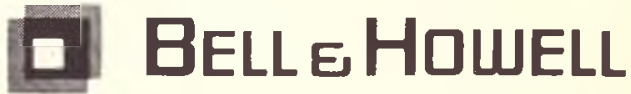

